\title{
Extradition as One of the Forms of Transfer of Detainees and Convicts. Albanian Experience
}

\author{
Ph.D Nikolin Hasani \\ University "Ismail Qemali" Vlore, Faculty of Human Sciences, Department of Law
}

\begin{abstract}
International mobility and migration have been increased due to the world globalization. This situation has affected international judicial cooperation, which has become of a special importance in managing issues linked to the pursuit and conviction of foreign citizens, as well as their extradition before or after a criminal sentence. Transfer of non-nationals convicted of a crime and sentenced to their home country, has become common practice. The transfer contributes to the rehabilitation of the sentenced person. The aim of this paper is to address the legal aspects of how it applies to the Albanian criminal legislation detainee and transfer of inmates, given that the Albanian society, a society in transition, has evolved and changed with quick steps while individual deprived of liberty does not concur with a fundamentally changed reality. Herein lays the purpose of the transfer as an opportunity for more steps towards re-integration of his resocialization.
\end{abstract}

Keywords: detains transfer, convicted transfer, exctradition.

\section{Introduction}

One of the reasons of transferring the enforcement of a custodial sentence is to make it easier for the sentenced person to re-adjust to a law-abiding life in the country in which he or she will be living after release. There always are conditions during international cooperation in criminal matters and the typical one is that the process must serve only those ends that are described in a request for cooperation. Extradition, where this basic idea is found, as an instrument of the judicial international cooperation, is one form of transfer of convicted and pursued person. This condition, enable the transfer of fugitives and at the same time serve as a guaranty that the person who is going to be extracted is not going to be prosecuting offences that are not specified in the request. Extradition also strictly respect individual terms agreed between the requesting and requested state. That means it serves as a restrictive instrument not to transfer the extradited person onward to a third state..

\section{Extradition as another form of transfer}

Another form of cooperation between countries to transfer prisoners or detainees is extradited, which it is one of the most successful format implemented in the framework of international cooperation in criminal matters, not only under the OK, but even by the European Council.Central role in the development of this mechanism has played the Council of Europe European Convention on Extradition with two additional protocols.

This convention has been ratified by our state that is in unison on this convention about how treats Extradition 1 .

\footnotetext{
${ }^{1}$ Hoxha,A.: Extradition by EU legal instruments. Similarities and differences with the instruments of the Council of Europe, Tirana 2010.
} 
The code of the Penal procedure ${ }^{1}$, article 488-504 establishes general rules: Submission of a person to a foreign country for the execution of a prison sentence or an act proving him for a criminal offense can be done only through extradition². Extradition shall be granted only on the basis of a request to the Ministry of Justice.

Demands for extradition are attached:

- a copy of the sentence of imprisonment or the act of proceedings;

- a report on the criminal offense charged to the person whose extradition is requested, indicating the time and place of the offense and its legal qualification;

- the text of the legal provisions to be applied, indicating whether for the offense for which extradition is provided by the law of a foreign state with the death penalty;

- personal data and any other information available which serves to establish the identity and nationality of the person subject to extradition.

When several extradition requests competing, the Ministry of Justice sets forth the order of examination. For this purpose it takes into account all the circumstances of the case and in particular the date of receipt of the request, the importance and place of the offense or nationality and residence of the person sought and the possibility of a re-extradition from the requesting state.

If for a single offense, extradition is requested simultaneously by several countries it is given to the state to which the criminal offense or to the country on whose territory the offense was committed.

Also are specified detailed conditions when can be allowed extradition. "Extradition is permitted provided expressed that the extradited can not be prosecuted, punished and not be handed over to another country for an offense that occurred before the request for extradition and which is different from that for which the extradition is given.

The above-mentioned conditions are not considered:

a) when extraditing side gives express consent to the extradition of prosecuted even for another criminal offense and has no objection to extradition;

b) when the extradited, although there have been opportunities, has not left the territory of the state to which it was delivered after spending forty-five days of his release or after leaving it returned voluntarily. The Ministry of Justice may impose other conditions as it considers appropriate "?

\section{The rejection of the extradition request}

A state can not always accept extradition, there are cases that the state can not allow the extradition, and this institute is called the rejection of the extradition request. Extradition can not be granted:

- $\quad$ for an offense with political character or if it turns out that he is requested for political purposes;

- $\quad$ when there are reasons to believe that the person sought will be subjected to persecution or discrimination due to race, religion, sex, nationality, language, political beliefs, personal or social status or other cruel punishments, or inhumane or degrading actions that constitute a violation of to fundamental human right;

- $\quad$ when the person sought has committed a criminal offense in Albania;

- $\quad$ when prosecution is initiated or has been tried in Albania even though the offense is committed abroad;

- $\quad$ when the offense is not envisaged as such by the Albanian legislation;

- $\quad$ when for the offense was given amnesty by the Albanian state;

- $\quad$ when the person sought is an Albanian citizen and there is no agreement predicting otherwise;

- $\quad$ when the prosecution is predicted or the punishment under state law that requires him.

\footnotetext{
${ }^{1}$ Law Nr.9911, dated 05.05.2008 "On Amendments to the Law No. 7905 dated: 03.21.1995" Criminal

Procedural Code of the Republic of Albania "after October 2004

${ }^{2}$ Article 488/489 of the Criminal Procedure Code
} 
Extradition is both active and passive types.

Active extradition or for the overseas it starts with an application that comes to the Justice Ministry, which forwards the request to the competent court when the conditions are completed. To this request are attached a number of documents proving the claim and make us realize that we are within our legal framework.

\section{The conditions for extradition}

The confitions for active extradition are:

- Rule of specialty.

- The principle of double sentence means the offense must be provided as such by the legislation of the two countries in the relationship.

- Extradition is not permitted when the person sought to be extradited is an Albanian citizen.

- Extradition is not permitted when the fact subject to extradition is a political offense or the person is requested for political reasons.

- $\quad$ Extradition is not permitted when the person to be extradited is subjected to persecution or discrimination.

- Its not given when a person has committed a criminal offense in the execution place of the request.

- The request is rejected and when prosecution, punishment or criminal acts have been prescribed in the requesting country.

- Rejection of extradition and when the subject is a military.

Pasiv extradition or from abroad, is the case when our county is requesting, not handover like above. We are before of this extradition form in cases where an Albanian citizen commits a crime within the Albanian territory and then leave abroad.

Prosecutor initiates proceedings and when the person finds nonexistence within the Albanian state sends a request to the Ministry of Justice, which after verifying the necessary conditions transmit the application to the competent authority where the person sought is.

Together with the request the Ministry forwards and the necessary documentation.

It may happen that the state executive accepts the request, but with conditions, if we are before this hypothesis the last word is from the Ministry of Justice, and what it decided is mandatory for the judiciary.

In general this is the mechanism of extradition and now we are able to give a definition of it: "Delivery of a person to a foreign country for the execution of a sentence of imprisonment or exercise of criminal prosecution."

And can easily determine its legal nature as dualistic because it is regulated both by international law and by the internal law. So, we see that it is a complicated procedure that did not justify itself, not responding to the request for a European area of freedom and security, leaving place to his successor UEN.

\section{European Prison Rules}

Even the Supplement ${ }^{1}$ of Recommendation No. R (87) 3 European Prison Rules, the European revised version of the Rules provides for minimum standards for treatment of prisoners, specifies that ${ }^{2}$ : "In case of death, serious illness or serious injury of a prisoner or sending it to an institution for treatment for mental illness, the director shall immediately inform the spouse, if the prisoner is married, or his nearest cousin and will inform for each event any other person previously assigned by the prisoner.

The prisoner shall be informed immediately of the death or serious illness of his relatives.

\footnotetext{
${ }^{1}$ Recommendation no. $R$ (87) 3 of the Committee of Ministers to member states on the European Prison Rules

${ }^{2}$ Notice of death, illness, transfer, etc...
} 
In these cases and whenever that circumstances allow, the prisoner should be authorized, either accompanied or alone, to visit a sick relative or see the deceased. All prisoners shall have the right to immediately inform their families of imprisonment or transfer to another institution. "

\section{Conclusions}

System treatment of prisoners is one of the key priorities in terms of consolidating the rule of law and guaranteeing human rights. The main goal is to improve conditions for the treatment of persons sentenced to imprisonment or detainees to ensure respect for their human rights and fundamental freedoms, in accordance with the regulations of the European Union, international treaties in force and internationally accepted standards.

Need of fulfillment of obligations arising from a number of international instruments to which Albania is a party, such as the European Convention for the Protection of Human Rights and Fundamental Freedoms, the European Convention for the Prevention of Torture and Treatment or Punishment Inhuman or Degrading as and fulfillment of EU recommendations.

Strengthening the security in prisons, through a special regime, which decided not only to the internal security of institutions, but also for external security, which aims mainly to prevent futher links with criminal world for persons serving prison sentences, for criminal offenses particularly dangerous, thus helping and their final separation from crime, reintegration, rehabilitation and further socialization.

In the criminal justice system, the execution of criminal judgments final and those with immediate execution, aimed at punishing and rehabilitating offenders who have committed offenses, the restoration of the rights of persons proceeded unfairly and rights of legal entities vulnerable to criminal acts, as well as their prevention.

Institutional viewpoint, execution of final criminal decisions is very important, but also complex. Institute of transfer aims to achieve not only a separation between convicted for various crimes in order not only to institutional security, but also social, but above all to give the opportunity of suffering the sentence near the settlement, in an environment known, familiar, to rehabilitate, economy, socialization.

\section{References}

[1] European Institute for Crime Prevention and Control, affiliated with the United Nations Enhancing International Law Enforcement Co-operation, including.

[2] Extradition Measures. Proceedings of the workshop held at the Eleventh United Nations Congress on Crime Prevention and Criminal Justice. Bangkok, Thailand, 18-25 April 2005.

[3] Ferraro, F.2013. EU rules on transfer of sentenced persons. Library of the European Parliament. 28.01.2013.

[4] Gillard, E.Ch.2008. International Review of the Red Cross. There's no place like home: states' obligations in relation to transfers of persons. Volume 90 Number 871 September 2008.

[5] Hoxha, A. 2010. Ekstradimi sipas instrumentave ligjore te BE. Ngjashmerite dhe ndryshimet me instrumentat e Keshillit te Europes. Tirane 2010.

[6] International Covenant on Civil and Political Rights, Article 10, paragraph 3.

[7] Kodi i proçedurës Penale Shqiptare, Neni 488/489.

[8] Ligji Nr.9911, datë 5.5.2008 "Për disa ndryshime në ligjin nr.7905 datë:21.3.1995 "Kodi i Proçedurës Penale i Republikës së Shqipërisë" i ndryshuar pas tetor 2004.

[9] Miettinen, S. 2013. Onward transfer under the European arrest warrant: is the EU moving towards the free movement of prisoners? New Journal of European Criminal Law, Vol. 4, Issue 1-2, 2013.

[10] Plachta, M. 1993. Human Rights Aspects of the Prisoner Transfer in a Comparative Perspective. Louisiana Law Review. Volume 53 | Number 4. March 199.3

[11] Rekomandimi Nr. R (87) 3 i Komitetit te Ministrave per shtetet anetare mbi Rregullat Evropiane te Burgut.

[12] United Nations Office on drugs and crime, Vienna. Cross - Cutting issues. International Cooperation Criminal Justice Assessment Toolkit. United Nations New York, 2006 